\title{
Partial mutual exclusion of ectomycorrhizal and saprobic fungi in a tropical seasonal rainforest
}

\section{Ediriweera $\mathrm{AN}^{1,2,3}$, Karunarathna $\mathrm{SC}^{1,2,3}, \mathrm{Xu} \mathrm{J}^{1,3}$, Hyde $\mathrm{KD}^{1,2,3}$, Mortimer $\mathrm{PE}^{1,3 *}$ and Schaefer $\mathrm{DA}^{1,2}$}

${ }^{1}$ Centre for Mountain Ecosystem Studies, Kunming Institute of Botany, Chinese Academy of Sciences, Kunming 650201, China

${ }^{2}$ Center of Excellence in Fungal Research, and School of Science, Mae Fah Luang University, Chiang Rai 57100, Thailand

${ }^{3}$ World Agroforestry Centre, East and Central Asia, 132 Lanhei Road, Kunming 650201, China

Ediriweera AN, Karunarathna SC, Xu J, Hyde KD, Mortimer PE, Schaefer DA 2020 - Partial mutual exclusion of ectomycorrhizal and saprobic fungi in a tropical seasonal rainforest. Asian Journal of Mycology 3(1), 1-12, Doi 10.5943/ajom/3/1/1

\begin{abstract}
Spatial distributions of ectomycorrhizal and saprotrophic fungi may differ in tropical forests for several reasons. If they do, it could have profound implications for carbon cycling across landscapes. We examined distributions of ectomycorrhizal and saprotrophic fungi in a 20 hectare forest study plot in China by collecting and identifying sporocarps (mushrooms) over two years. We found that for sporocarp numbers, species, and contributions to Shannon diversity, saprotrophic fungi were highest near stream channels and decreased with distance therefrom. Ectomycorrhizal species numbers and contributions to Shannon diversity were highest in plots most distant from stream channels. Earlier research here showed soil phosphorus availability to decrease away from stream channels, and ectomycorrhizal fungi should be favored where soil phosphorus is low. Aggressive negative interactions between these fungal guilds should intensify this pattern. We suggest that litter decomposition rates here should be highest near stream channels, because of strong domination by saprotrophic fungi.
\end{abstract}

Key words - ectomycorrhizal fungi - saprobic fungi - stream side ecology - tropical forests Xishuangbanna

\section{Introduction}

Phosphorus (P) is the nutrient thought to most strongly limit plant growth in lowland tropical and subtropical forests (Vitousek 1984, Vitousek et al. 2010, Condit et al. 2013). Ectomycorrhizal (ECM) fungi were historically considered rare or absent from tropical ecosystems, but have been found in many forests (Corrales et al. 2018). Where detailed studies have been done, ECM associations were linked to low nutrient availability (Gartlan et al. 1986, Corrales et al. 2018).

Ectomycorrhizal fungi form symbioses with plant roots (Smith \& Reed 2008) and extract phosphorus from large soil volumes and from soil chemicals not directly available to plant roots (Bolan 1991, Plassard \& Dell 2010, Cairney 2011, Zhang et al. 2014). In return, they receive labile carbon directly from plant roots (Smith \& Reed 2008). In contrast, saprobic (SAP) fungi live independently in soils and obtain their phosphorus and carbon solely by excretion of extracellular enzymes (Baldrian 2008). Some enzymes involved in extracellular digestion have been found in 
ECM fungi (Lindahl \& Tunlid 2015), and ECM competes with decomposer microorganisms for access to organic N and P from the litter (Read \& Perez-Moreno 2003).

In addition, these two fungal groups have negative interactions limiting their local coexistence (Singer \& Araujo 1979, Lindahl 2000, Leake et al. 2001, McGuire et al. 2013, Marian et al. 2019). The ability of ECM fungi to perform slow saprobic decomposition of plant litter has been termed the "Gadgil Effect" (Fernandez \& Kennedy 2016) and demonstrated in tropical forests (McGuire et al. 2010, Averill \& Hawkes 2016). Both types disseminate spores via the production of fruiting bodies (mushrooms) that can be identified to species by traditional methods (Watling et al. 1995, Watling 2001, Henkel et al. 2011).

Besides soil properties affecting fungal communities, forest-floor litter is transferred downslope by overland water flow towards stream channels (Ghahramani et al. 2011, Bilby \& Heffner 2016), potentially providing more resources for saprobic fungi in lower areas.

The tropical seasonal rainforest of Xishuangbanna is one of the most species-rich forest ecosystems in China (Cao \& Zhang 1997). It is a biodiversity hotspot which contains over 5000 species of vascular plants, comprising $16 \%$ of the total plant diversity in China. It is therefore of great importance to global biodiversity conservation (Cao et al. 2008). Extensive research at Xishuangbanna Tropical Seasonal Rainforest Dynamics Plot (XTRDP) includes identification, location and mensuration of all tree stems (Lan et al. 2012) and spatially-explicit measurements of canopy litterfall and soil chemistry (Xia et al. 2015).

We hypothesized that ECM and SAP fungi have different spatial patterns across XTRDP, and collected and identified their mushrooms to examine that. We established replicated plots within 1 $\mathrm{m}$ of stream channels, those $>1$ and $<160 \mathrm{~m}$ from stream channels, and those $>160 \mathrm{~m}$ from stream channels. Those selections well-represent the entire Bubeng plot. We anticipated negative interactions between ECM and SAP fungi to differ across space, but previous research has examined this in low-disturbance tropical forests with high topographic variability.

\section{Materials and Methods}

\section{Site selection and specimen collection}

The site of this study was in Xishuangbanna, China at $21^{\circ} 08^{\prime}$ and $22^{\circ} 36^{\prime} \mathrm{N}, 99^{\circ} 56^{\prime}$ and $101^{\circ} 50^{\prime}$ E. Xishuangbanna covers an area of $19120 \mathrm{~km}^{2}$ that has mountainous topography and a typical monsoon climate (Cao et al. 2008). The annual mean temperature is $21.8^{\circ} \mathrm{C}$, and annual mean precipitation is $1493 \mathrm{~mm}$, of which about $85 \%$ occurs in the rainy season between May to October. The dry season lasts from November to April (Cao et al. 2008).

The 20-ha XTRDP (Fig. 1) was established in a Parashorea chinensis forest within Mengla County, Xishuangbanna Prefecture, Yunnan Province, south western China. Mengla borders with

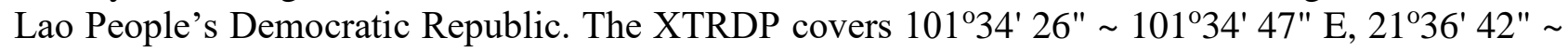
$21^{\circ} 36^{\prime} 58^{\prime \prime} \mathrm{N}$ and its canopy height is 40 to 60 , with three tree layers plus a shrub and herbaceous layer. The XTRDP is rectangular and measures $400 \mathrm{~m}$ (north-south) by $500 \mathrm{~m}$ (east-west). The elevation of the plot ranges from 709 to $869 \mathrm{~m}$ above sea level, with the highest elevation in the northwest of the plot (Fig. 1).

The upper canopy is dominated by Parashorea chinensis, Salonea tomentosa (Benth.) Rehder \& E.H. Wilson, Pometia tomentosa (Blume) Teijsm. \& Binn., Semecarpus reticulate Lecomte, and Barringtonia pendula Kurz. The lower canopy mainly consists of Garcinia cowa Roxb, Knema furfuracea (Hook. F. \& Thomson) Warb, Nephelium chryseum Blume, Cinnamomum bejolghota (Buch.-Ham.) Sweet, Baccaurea ramiflora Lour., Pittosporopsis kerrii Craib., Mezzettiopsis creaghii Ridl., Saprosma ternate Hook. F, and Leea compactiflora Kurz (Cao et al. 2008).

Three perennial streams run through this 20-ha plot and converge near the southeastern corner. The distance between their entry to the plot and their point of convergence is $800 \mathrm{~m}, 500 \mathrm{~m}$, and $450 \mathrm{~m}$ and have average widths of 8,6 and $6.5 \mathrm{~m}$ respectively. These streams are shaded by the canopies of the tree species Garcinia cowa, Cinnamomum bejolghota, Knema furfuracea (Hook. F. \& Thomson) and Diospyros hasseltii Zoll. Various species of macrofungi grow on both sides of 
these streams and at higher elevations, with their distribution and growth being determined by environmental factors, including light, moisture, temperature and essential nutrients.

For this study, $400 \mathrm{~m}^{2}$ area of each site (site A is within $1 \mathrm{~m}$ of streams, site B was 1 to $160 \mathrm{~m}$ away and site $\mathrm{C}$ was further than $160 \mathrm{~m}$ from the stream) was selected from each creek with 6 replicates from each site. We selected $400 \mathrm{~m}^{2}$ areas from both sides (left and right facing upstream) of three streams (Fig. 1). The $400 \mathrm{~m}^{2}$ area consisted of 400 plots of $1 \mathrm{~m} \times 1 \mathrm{~m}$ where the minimum distance between two plots was $1 \mathrm{~m}$ and the maximum distance between two plots was $3 \mathrm{~m}$. Macrofungal sporocarps were collected from July to October in 2014 and 2015 into individual polyethylene bags.
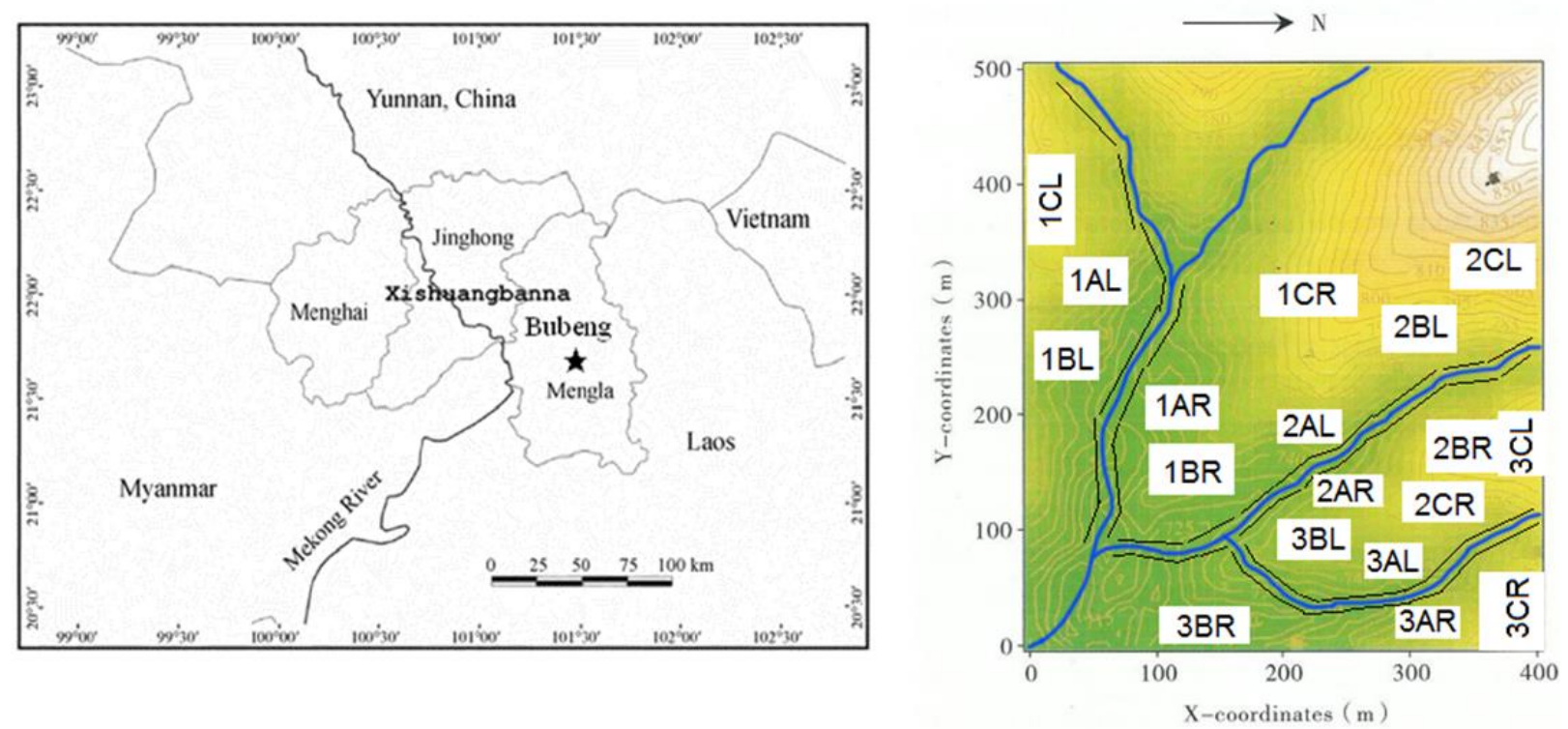

Fig. 1 - Left panel. Location of the 20-hectare tropical seasonal rainforest dynamics plot in Xishuangbanna, southwest China. Right panel. Elevation map of the 20-hectare plot with $5 \mathrm{~m}$ contours. Approximate locations of sampling sites and plots are also shown. See text for additional details.

\section{Identification of sporocarps}

All specimens of macrofungi were examined in the laboratory. Records were made of apparent macromorphological characteristics such as colour, shape and size of the macrofungi cap, stipe, gills and other characteristics such as odour, colour changes and habitat. Spore prints were made to determine the colour of the basidiospores and were then used for basidiospore measurements. Microscopic examinations were performed using Nikon Model Eclipse Ci-s research microscopes. Characteristics of macrofungi, colour of spore print, microscopic analysis, books, monographs (Corner 1966, Guzmán 1983, 1968, Phillips 1981, Moser 1983, Arora 1986) and journal articles (Das et al. 2013, Itoo et al. 2013, Lodge \& Overbo 2008, He et al. 2010) were used to identify most of the macrofungi specimens to species level. The taxonomic classification of species was based on Kirk et al. (2008), and Index Fungorum (2017) was followed for the nomenclature. After examination, specimens were dried in a portable food dryer for 24-32 hours at $35^{\circ} \mathrm{C}$ and were sealed separately in polyethylene bags.

\section{Data analysis}

To calculate diversity of macrofungi in different sites, Shannon's diversity index (shown below) was used, where $\mathrm{H}=$ the Shannon diversity index; $\mathrm{Pi}=$ fraction of the entire population made up of species; $\mathrm{S}=$ numbers of species encountered; $\sum=$ sum from species 1 to species $\mathrm{S}$. 


$$
H=-\sum_{j=1}^{S} p_{i} \ln p_{i}
$$

Each of those species collected contributes to Shannon diversity. The contribution to Shannon Diversity index for all SAP and ECM fungi was calculated.

\section{Results}

Across $3600 \mathrm{~m}^{2}$ of Bubeng plot sampled during peak emergence periods over two years, 25678 SAP and 9946 ECM sporocarps were collected and identified to species. They included 66 SAP and 38 ECM species. Their distributions were strikingly non uniform and in many cases were related to distances from stream channels. The general pattern was the domination of saprobes along the stream sides, while high ECM species richness and diversity increased further away from streams. Support for and exceptions to this pattern are described below.

Three of the 4 most abundant SAP fungi species were uniformly distributed across sampling sites (Microporus xanthopus, Trametes versicolor and Pleurotus ostreatus) (Table 1). Other saprobes more abundant than any Basidiomycete ECM species had 4 of 5 species limited to streamside sites; Microporus affinis, Polyporus squamosus, Polyporus badius and Polyporus brumalis (Table 1). At lower species abundances down to 172 individuals identified, 22 of 32 SAP species were limited to streamside sites (Table 1). Ascomycete SAP species were completely restricted to streamside sites (Table 1).

The most abundant Ascomycete ECM species was found in all 3 sites (Xylaria cubensis, Table 2), but Ascomycete Xylaria longipes was restricted to stream sides, opposing general pattern seen here. The three Basidiomycete ECM species in terms of abundance (Laccaria laccata, Lactarius sanguifluus and Russula maculata) also did not support general patterns seen here, being either found across sites or restricted to stream sides (Table 2). At lower species abundances down to 88 individuals identified, 17 of 19 ECM species were absent from streamside sites, and generally more abundant in plots of site $\mathrm{C}$ furthest from stream channels (Table 2).

Streamside site A plots averaged 2804 individuals of 39 saprobic species and 760 individuals of 9 ECM species (Tables 1, 2), with $80 \%$ of Shannon diversity from saprobic species (Fig. 2). Site B plots more distant from streams averaged 1067 individuals of 20 saprobic species and 329 individuals of 15 ECM species (Tables 1,2), with $72 \%$ of Shannon diversity from saprobic species (Fig. 2). Site $\mathrm{C}$ plots furthest from streams averaged 409 individuals of 15 saprobic species and 569 individuals of 26 ECM species (Tables 1,2), with only $44 \%$ of Shannon diversity from saprobic species (Fig. 2).

Of 66 SAP species, 39 were restricted to streamside site A plots, while only 8 were found in all 3 sites (Table 1). Only 16 saprobic species were absent from Site A. Of 38 ECM species, 28 were absent from streamside site A plots, while only 2 were found in all 3 sites (Table 2).

In summary, the most abundant SAP and ECM species were either ubiquitous or their distributions opposed this overall spatial patterning. Those species did not appear sensitive to aggressive effects of the other feeding type, or to soil chemical or other spatial patterns. Mutual partial exclusion of fungal feeding types arose from species of intermediate abundance.

\section{Discussion}

Down slope transfer of forest-floor litter has been demonstrated elsewhere (Ghahramani et al. 2011, Bilby \& Heffner 2016), and would provide additional resources for SAP fungi near to stream channels. However, leaf and wood litter are abundant in all areas of this forest, so saprotrophic limitations far from stream channels does not seem likely. ECM dominance of fungal communities most distant from streams cannot be ascribed to soils being always wet near streams, because densities of ECM sporocarps were highest in streamside plots. Rather it is that SAP 
species, numbers and diversity fall with distances from stream. Meanwhile, ECM species richness and diversities increased further from the stream channels.

A more probable explanation can be drawn from Xia et al. (2015), who found that the available phosphorus in the forest soil was highest near stream channels. It decreased approximately four-fold in areas most distant from stream channels that they measured. Other research shows that ECM are favored in areas of low soil nutrient availability, including that of phosphorus (e.g. Read \& Perez-Moreno 2003, Corrales et al. 2018).

Table 1 Saprotrophic sporocarps collected from Bubeng Tropical Seasonal Rainforest Dynamics Plot (XTRDP) at Xishuangbanna, China. Orders in bold are Ascomycetes and others Basidiomycetes. Species are listed in decreasing order of total sporocarp numbers collected. Sites A, B and C refer to distances from stream channels (see text). In each site, six plots were sampled and means and (standard deviations) are presented. Blanks indicate species were absent from sites. Values in bold red indicate species whose distributions particularly support community pattern of saprotrophs.

\begin{tabular}{|c|c|c|c|c|c|}
\hline Order & Species name (saprotrophic) & Total sporocarps & $\begin{array}{c}\text { Site A plot means } \\
\text { (std dev) }\end{array}$ & $\begin{array}{c}\text { Site B plot means } \\
\text { (std dev) }\end{array}$ & $\begin{array}{c}\text { Site C plot means } \\
\text { (std dev) }\end{array}$ \\
\hline Polyporales & Microporus xanthopus & 3737 & $253(125)$ & $261(79)$ & $109(22)$ \\
\hline Polyporales & Trametes versicolor & 3234 & $271(41)$ & $202(5)$ & $66(30)$ \\
\hline Xylariales & Xylaria cubensis & 3148 & $292(45)$ & $158(17)$ & $75(13)$ \\
\hline Polyporales & Microporus affinis & 1594 & $266(106)$ & & \\
\hline Xylariales & Xylaria longipes & 1170 & $195(148)$ & & \\
\hline Agaricales & Pleurotus ostreatus & 1223 & $80(36)$ & $81(3)$ & $44(17)$ \\
\hline Polyporales & Polyporus squamosus & 1094 & 182 129) & & \\
\hline Polyporales & Polyporus badius & 906 & $151(107)$ & & \\
\hline Polyporales & Ganoderma lucidum & 871 & $2(5)$ & $143(25)$ & \\
\hline Polyporales & Polyporus brumalis & 847 & $141(94)$ & & \\
\hline Agaricales & Crucibulum leave & 625 & $41(34)$ & $29(19)$ & $35(2)$ \\
\hline Pezizales & Cookeina tricholoma & 628 & $105(74)$ & & \\
\hline Polyporales & Polyporus leptocephalus & 580 & $97(63)$ & & \\
\hline Pezizales & Cookeina venezuelae & 530 & $88(62)$ & & \\
\hline Polyporales & Ceriporiopsis merulinus & 476 & $79(99)$ & & \\
\hline Agaricales & Marasmius oreades & 462 & & $50(15)$ & $27(8)$ \\
\hline Geastrales & Geastrum fimbriatum & 455 & $76(6)$ & & \\
\hline Agaricales & Marasmiellus ramealis & 432 & $72(14)$ & & \\
\hline Geastrales & Geastrum triplex & 407 & & $35(12)$ & $33(3)$ \\
\hline Agaricales & Lentinula edodes & 404 & & $67(27)$ & \\
\hline Auriculariales & Auricularia auricula-judae & 400 & $67(10)$ & & \\
\hline Agaricales & Panellus stipticus & 351 & $59(34)$ & & \\
\hline Agaricales & Lepiota helveola & 349 & & $38(23)$ & $20(6)$ \\
\hline Polyporales & Daedalea sp & 307 & $51(20)$ & & \\
\hline Agaricales & Mycena leaiana & 306 & $21(13)$ & $18(4)$ & $13(2)$ \\
\hline
\end{tabular}


Table 1 Continued.

\begin{tabular}{|c|c|c|c|c|c|}
\hline Order & Species name (saprotrophic) & Total sporocarps & $\begin{array}{c}\text { Site A plot means } \\
\text { (std dev) }\end{array}$ & $\begin{array}{c}\text { Site B plot means } \\
\text { (std dev) }\end{array}$ & $\begin{array}{c}\text { Site C plot means } \\
\text { (std dev) }\end{array}$ \\
\hline Agaricales & Stropharia ambigua & 299 & $18(12)$ & $17(2)$ & $15(2)$ \\
\hline Auriculariales & Auricularia delicate & 296 & $46(20)$ & $4(9)$ & \\
\hline Agaricales & Marasmius rotula & 265 & $44(28)$ & & \\
\hline Agaricales & Pleurotus citrinopileatus & 260 & $43(25)$ & & \\
\hline Agaricales & Marasmius bulliardii & 256 & $43(34)$ & & \\
\hline Polyporales & Neofavolus alveolaris & 255 & $4341)$ & & \\
\hline Geastrales & Geastrum floriforme & 248 & $41(38)$ & & \\
\hline Geastrales & Geastrum saccartum & 247 & $41(31)$ & & \\
\hline Pezizales & Phillipsia domingensis & 247 & $41(29)$ & & \\
\hline Polyporales & Nigroporus durus & 244 & $41(22)$ & & \\
\hline Agaricales & Marasmius siccus & 232 & $39(28)$ & & \\
\hline Agaricales & Marasmius epiphyllus & 231 & $39(36)$ & & \\
\hline Pezizales & Phillipsia hartmannii & 208 & $35(32)$ & & \\
\hline Agaricales & Pleurotus eryngii & 197 & & $33(12)$ & \\
\hline Agaricales & Collybia cookei & 183 & $31(10)$ & & \\
\hline Auriculariales & Auricularia polytricha & 183 & & $31(2)$ & \\
\hline Agaricales & Collybia dryophila & 172 & $29(9)$ & & \\
\hline Agaricales & Hymenopellis radicata & 165 & $28(12)$ & & \\
\hline Agaricales & Micropsalliota globocystis & 157 & & $13(2)$ & $14(5)$ \\
\hline Agaricales & Collybia umbonata & 148 & $25(8)$ & & \\
\hline Agaricales & Mycena galopus & 144 & $24(4)$ & & \\
\hline Hymenochaetales & Phellinus gilvus & 144 & $24(37)$ & & \\
\hline Agaricales & Psathyrella hydrophila & 121 & & $11(1)$ & $9(3)$ \\
\hline Polyporales & Tyromyces chioneus & 85 & & $3(2)$ & $12(3)$ \\
\hline Agaricales & Agaricus campestris & 81 & $2(5)$ & $5(1)$ & $6(4)$ \\
\hline Polyporales & Trametes trogii & 68 & $6(15)$ & $3(8)$ & $2(5)$ \\
\hline Agaricales & Xerula radicata & 55 & & $7(3)$ & $2(4)$ \\
\hline Agaricales & Hypsizygus tessellatus & 44 & & $7(8)$ & \\
\hline Agaricales & Agaricus bisporus & 31 & $5(13)$ & & \\
\hline Agaricales & Pleurotus pulmonarius & 26 & $4(11)$ & & \\
\hline Agaricales & Entoloma strictius & 25 & $2(6)$ & $2(4)$ & \\
\hline Agaricales & Marasmius sullivantii & 24 & $4(10)$ & & \\
\hline Agaricales & Crepidotus mollis & 21 & & $4(9)$ & \\
\hline Agaricales & Pleurotus australis & 14 & & $2(6)$ & \\
\hline Agaricales & Crepidotus crocophyllus & 13 & $2(5)$ & & \\
\hline
\end{tabular}


Table 1 Continued.

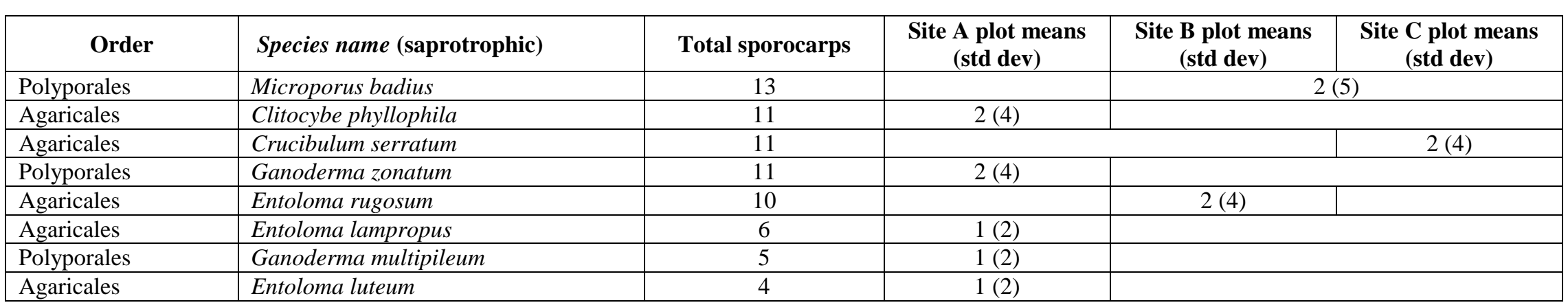

Three of the 4 most abundant SAP species were uniformly distributed across sampling sites (Microporus xanthopus, Trametes versicolor and Pleurotus ostreatus) (Table 1). Other saprobes more abundant than any Basidiomycete ECM species had 4 of 5 species limited to streamside sites; Microporus affinis, Polyporus squamosus, Polyporus badius and Polyporus brumalis (Table 1). At lower species abundances down to 172 individuals identified, 22 of 32 SAP species were limited to streamside sites (Table 1). Ascomycete SAP species were completely restricted to streamside sites (Table 1).

Table 2 Ectomycorrhizal sporocarps collected from Bubeng Tropical Seasonal Rainforest Dynamics Plot (XTRDP) at Xishuangbanna, China. Orders in bold are Ascomycetes and others Basidiomycetes. Species are listed in decreasing order of total sporocarp numbers collected. Sites A, B and C refer to distances from stream channels (see text). In each site, six plots were sampled and means and (standard deviations) are presented. Blanks indicate species were absent from sites. Values in bold red indicate species whose distributions particularly support community pattern of ectomycorrhizae being more dominant away from stream channels (see text).

\begin{tabular}{|c|c|c|c|c|c|}
\hline Order & Species name (Eectomycorrhizal) & Total sporocarps & $\begin{array}{c}\text { Site A plot means } \\
\text { (std dev) }\end{array}$ & $\begin{array}{c}\text { Site B plot means } \\
\text { (std dev) }\end{array}$ & $\begin{array}{c}\text { Site C plot means } \\
\text { (std dev) }\end{array}$ \\
\hline Agaricales & Laccaria laccata & 658 & $44(51)$ & $30(5)$ & $35(3)$ \\
\hline Russulales & Lactarius sanguifluus & 625 & $104(102)$ & & \\
\hline Russulales & Russula maculata & 444 & $52(64)$ & & $22(3)$ \\
\hline Boletales & Xerocomus communis & 317 & & $23(3)$ & $75(13)$ \\
\hline Boletales & Boletus edulis & 230 & & $16(2)$ & $22(2)$ \\
\hline Boletales & Suillus luteus & 223 & & & $37(2)$ \\
\hline Boletales & Tylopilus violatinctus & 197 & & $13(1)$ & $20(2)$ \\
\hline Boletales & Boletus bicolor & 193 & & $16(7)$ & $17(3)$ \\
\hline Boletales & Strobilomyces polypyramis & 192 & & $9(2)$ & $23(3)$ \\
\hline Cantharellales & Cantharellus cibarius & 192 & & $13(1)$ & $20(3)$ \\
\hline
\end{tabular}


Table 2 Continued.

\begin{tabular}{|c|c|c|c|c|c|}
\hline Order & Species name (Eectomycorrhizal) & Total sporocarps & $\begin{array}{c}\text { Site A plot means } \\
\text { (std dev) }\end{array}$ & $\begin{array}{c}\text { Site B plot means } \\
\text { (std dev) }\end{array}$ & $\begin{array}{c}\text { Site C plot means } \\
\text { (std dev) }\end{array}$ \\
\hline Boletales & Suillus granulates & 191 & & & $32(13)$ \\
\hline Russulales & Lentinus crinitus & 187 & $31(26)$ & & \\
\hline Agaricales & Cortinarius orellanosus & 186 & $31(8)$ & & \\
\hline Boletales & Xerocomus subtomentosus & 172 & & & $29(3)$ \\
\hline Boletales & Xerocomus truncates & 147 & & & $25(4)$ \\
\hline Agaricales & Amanita vaginata & 140 & & $1(2)$ & $23(2)$ \\
\hline Russulales & Lactarius pyrogalus & 125 & & & $21(1)$ \\
\hline Boletales & Boletus speciosus & 123 & & $21(9)$ & \\
\hline Agaricales & Amanita virosa & 118 & & $6(4)$ & $13(4)$ \\
\hline Boletales & Phlebopus portentosus & 113 & & $7(1)$ & $12(2)$ \\
\hline Russulales & Russula emetica & 99 & & & $17(2)$ \\
\hline Russulales & Lactarius piperatus & 88 & & & $15(4)$ \\
\hline Agaricales & Amanita flavorubescens & 83 & $2(2)$ & $1(1)$ & $11(5)$ \\
\hline Agaricales & Laccaria bicolor & 76 & & & $13(3)$ \\
\hline Agaricales & Laccaria proxima & 75 & & & $13(2)$ \\
\hline Agaricales & Cortinarius flexipes & 74 & & & $12(6)$ \\
\hline Boletales & Boletellus emodensis & 69 & & & $12(2)$ \\
\hline Thelephorales & Thelephora ganbajun & 69 & & $12(4)$ & \\
\hline Agaricales & Cortinarius fulviconicus & 56 & & & $9(2)$ \\
\hline Agaricales & Amanita rubrovolvata & 53 & & & $9(2)$ \\
\hline Boletales & Scleroderma citrinum & 39 & $7(4)$ & & \\
\hline Boletales & Strobilomyces strobilaceus & 33 & & $2(5)$ & $4(9)$ \\
\hline Boletales & Boletus badius & 16 & & $3(7)$ & \\
\hline Agaricales & Inocybe rimosa & 11 & $2(4)$ & & \\
\hline Thelephorales & Thelephora terrestris & 10 & & $2(4)$ & \\
\hline Agaricales & Inocybe geophylla & 4 & & & $1(2)$ \\
\hline
\end{tabular}

Edaphic patterns influence fungal distributions in XTRDP. Widely reported aggressive interactions between ECM and SAP (e.g. Leake et al. 2001, McGuire et al. 2013, Marian et al. 2019) would intensify community differences across space. However, it must be noted that the most abundant ECM and SAP species were indifferent to such patterns. Instead, community differences arose from patterns of species of intermediate abundance. We are not aware of previous research showing this. 

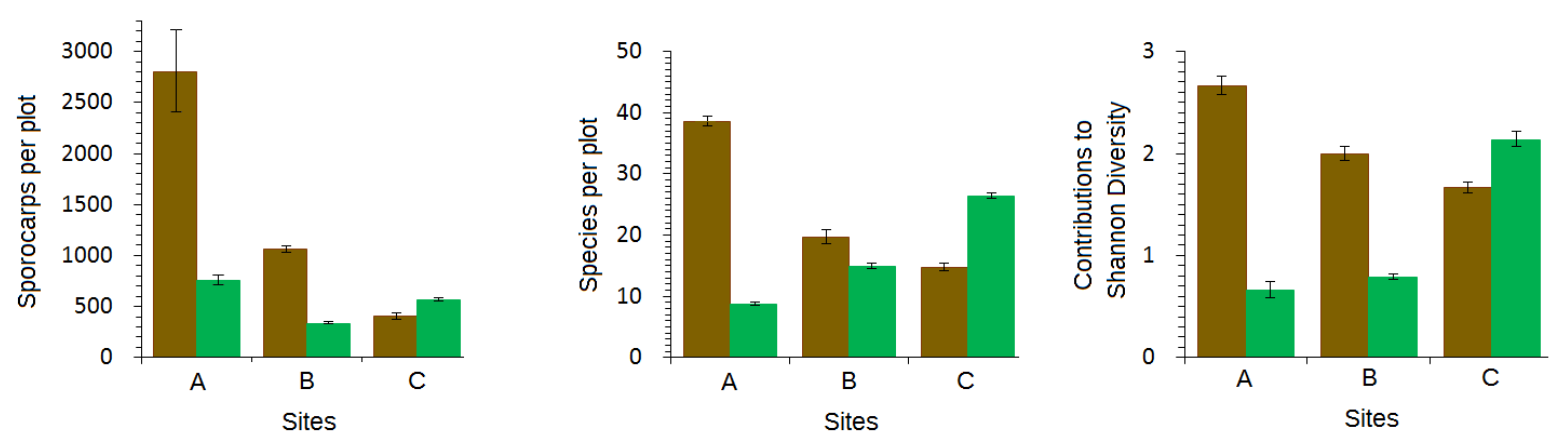

Fig. 2 - Distributional patterns of saprotrophic (brown) and ectomycorrhizal (green) macrofungal sporocarps collected from Bubeng Tropical Seasonal Rainforest Dynamics Plot at Xishuangbanna, China. Site A is within 1 meter of stream channels, site B is $>1$ meter and $<160$ meters from stream channels, site $\mathrm{C}$ is $>160$ meters from stream channels. Each site has 6 plots totaling $1200 \mathrm{~m} 2$ sampled area. Sporocarps per plot, species per plot and contributions to Shannon diversity are shown separately. Statistical dispersions are standard deviations over 6 plots. See text for additional details.

In the Korup Forest Dynamics Plot in Cameroon, ECM distributions varied across space (Bechem et al. 2014) but were not related to soil-phosphorus distributions (Gartlan et al. 1986). This distinction may relate to the fact that tree species hosting ECM in tropical Africa mostly host nitrogen-fixing bacteria as well (Bâ et al. 2012); a pattern absent from Asian tropical forests. So, soil-nutrient availability may not always be the driving force for macrofungal distributions in tropical forests.

Studies assessing ECM based on identifiable sporocarps above the litter layer might miss underground sporocarps. Our sampling over two years covered the entire period of sporocarp emergence for both ECM and SAP in this forest, so incomplete sampling is unlikely.

Effects from limitations from soil chemistry or interactions on this fungal community were incomplete, as the most abundant saprobic and ectomycorrhizal species did not respond to them. However, the rest of the fungal community did, and created patterns were observed in the current study. In this tropical forest, some aspects of the Gadgil effect (negative interactions between ECM and SAP structuring fungal communities; Gadgil \& Gadgil 1971, Lindahl 2000, Leake et al. 2003) have been demonstrated. This raises questions as to whether plant-litter or soil organic matter decomposition rates vary spatially in XTRDP, similar to other studies which have shown fungal community differences (Cairney \& Meharg 2002, Averill \& Hawkes 2016, Fernandez \& Kennedy 2016, Corrales et al. 2018). That would be a complete local demonstration of the Gadgil effect and could be examined by leaf litter and buried soil (organic matter) decomposition studies across the XTRDP, using appropriately sized mesh bags. Those could have implications for carbon cycling in other tropical forests, where soil-phosphorus levels also vary and may alter fungal community structure and function. Fungal spatial patterns shown here may be seen both as an example of, and a tool available for exploration of tropical carbon cycling.

\section{Acknowledgements}

Kevin D. Hyde thanks the Chinese Academy of Sciences, project number 2013T2S0030, for the award of Visiting Professorship for Senior International Scientists at Kunming Institute of Botany. This study was funded by the Chinese Ministry of Science and Technology, under the 12th five-year National Key Technology Support Program (NKTSP)2013BAB07B06 for integration and comprehensive demonstration of key technologies on Green Phosphate-Mountain Construction; the CGIAR Research Program 6: Forest, Trees and Agroforestry; Thailand Research Fund grant - 
Taxonomy, Phylogeny and Biochemistry of Thai Basidiomycetes (BRG 5580009); the National Research Council of Thailand

NRCT) projects - Taxonomy, Phylogeny and Cultivation of Lentinus species in northern Thailand (NRCT/55201020007); and Mae Fah Luang University, project - Taxonomy, Phylogeny and Cultivation of Lentinus species in Northern Thailand (MFU/54 1010200 48).

\section{References}

Arora D. 1986 - Mushrooms Demystified. Ten Speed Press, New York.

Averill C, Hawkes CV. 2016 - Ectomycorrhizal fungi slow soil carbon cycling. Ecology Letters 19, 937-947.

Bâ AM, Duponnois R, Moyersoen B, Diédhiou AG. 2012 - Ectomycorrhizal symbiosis of tropical African trees. Mycorrhiza 22, 1-29.

Baldrian P. 2008 - Enzymes of saprotrophic basidiomycetes. In: Boddy L, Frankland JC, van West P, (Eds.), Ecology of Saprotrophic Basidiomycetes. British Mycological Society Symposia Series. Elsevier 28, 19-41.

Bechem EET, Chuyong GB, Fon BT. 2014 - A survey of mycorrhizal colonization in the 50-ha Korup Forest Dynamic Plot in Cameroon. American Journal of Plant Sciences 5, 1403-1415.

Bilby RE, Heffner JT. 2016 - Factors influencing litter delivery to streams. Forest Ecology and Management 369, 29-37.

Bolan NS. 1991 - A critical review on the role of mycorrhizal fungi in the uptake of phosphorus by plants. Plant and Soil 134, 189-207.

Cairney JWG. 2011 - Ectomycorrhizal fungi: the symbiotic route to the root for phosphorus in forest soils. Plant and Soil 44, 51-71.

Cairney JWG, Meharg AA. 2002 - Interactions between ectomycorrhizal fungi and soil saprotrophs: implications for decomposition of organic matter in soils and degradation of organic pollutants in the rhizosphere. Canadian Journal of Botany 80, 803-809.

Cao M, Zhang J. 1997 - Tree species diversity of tropical forest vegetation in Xishuangbanna, SW China. Biodiversity Conservation 6, $995-1006$.

Cao M, Zhu H, Wang H, Lan GY et al. 2008 - Xishuangbanna Tropical Seasonal Rainforest Dynamics Plot: Tree Distribution maps, Diameter tables and Species Documentation. Yunnan Science and Technology Press, Kunming.

Condit R, Engelbrecht BMJ, Pino D, Pérez R, Turner BL. 2013 - Species distributions in response to individual soil nutrients and seasonal drought across a community of tropical trees. Proceedings of the National Academy of Sciences USA 110, 5064-5068.

Corner EJH. 1966 - A Monograph of Cantharelloid Fungi. Oxford University Press, London.

Corrales A, Henkel TW, Smith ME. 2018 - Ectomycorrhizal associations in the tropics biogeography, diversity patterns and ecosystem roles. New Phytologist 220, 1076-1091.

Das AR, Das P, Bhattacharjee S, Saha AK. 2013 - Chemical analysis of a wild edible mushroom: Pleurotus djamor (Rumph. ex Fr.) Boedijn. Mushroom Research 23, 161-166.

Fernandez CW, Kennedy PG. 2016 - Revisiting the 'Gadgil effect': do interguild fungal interactions control carbon cycling in forest soils? New Phytologist 209, 1382-1394.

Gadgil RL, Gadgil PD.1971 - Mycorrhiza and litter decomposition. Nature 233: 133.

Gartlan JS, Newbery DM, Thomas DW, Waterman PG. 1986 - The influence of topography and soil phosphorus on the vegetation of Korup Forest Reserve, Cameroun. Vegetatio 65, 131148.

Ghahramani A, Ishikawa Y, Gomi T. 2011 - Slope length effect on sediment and organic litter transport on a steep forested hillslope: upscaling from plot to hillslope scale. Hydrological Research Letters 5, 16-20.

Guzmán G.1968 - New species of Psilocybe of the Section Caerulescentes of the coniferous forests of Mexico. Annals of the National School of Biological Sciences 17, 9-16.

Guzmán G.1983 - The genus Psilocybe. Beih. Nova Hedwigia. 74, Cramer, Vaduz. 
He XL, Li TH, Jiang ZD. 2010 - Three species of white Entoloma new to China. Mycosystema 29, 920-923

Henkel TW, Aime MC, Chin MML, Miller SL et al. 2011 - Ectomycorrhizal fungal sporocarp diversity and discovery of new taxa in Dicymbe monodominant forests of the Guiana Shield. Biodiversity and Conservation 21, 2195-2220.

Index Fungorum. 2017 - Available from http://www.indexfungorum.org/Names/Names.asp (Accessed 13 March 2017)

Itoo ZA, Reshi ZA, Andrabi KI. 2013 - Characterization and identification of Russula firmula and Russula postiana from Himalayan moist temperate forests of Kashmir, African Journal of Biotechnology 12, 3643-3647.

Kirk PM, Cannon PF, Minter DW, Stalpers JA. 2008 - Dictionary of the Fungi. 10th Ed. CAB International, Wallingford, UK.

Lan G, Zhu H, Cao M. 2012 - Tree species diversity of a 20-ha plot in a tropical seasonal rainforest in Xishuangbanna, southwest China. Journal of Forestry Research 17, 432-439.

Leake JR, Donnelly DP, Saunders EM, Boddy L, Read DJ. 2001 - Rates and quantities of carbon flux to ectomycorrhizal mycelium following 14C pulse labeling of Pinus sylvestris seedlings: effects of litter patches and interaction with a wood-decomposer fungus. Tree Physiology 21, 71-82.

Leake JR, Donnelly DP, Boddy L. 2003 - Interactions between ectomycorrhizal and saprotrophic fungi. In: Van der Heijden MGA, Sanders IR, (Eds.), Ecological Studies 157, 345-372.

Lindahl B. 2000 - Ectomycorrhizal fungi raid saprotrophic ones. Mycological Research 104, 386387.

Lindahl BD, Tunlid A. 2015 - Ectomycorrhizal fungi-potential organic matter decomposers, yet not saprotrophs. New Phytologist 205, 1443-1447.

Lodge DJ, Ovrebo CL. 2008 - First records of Hygrophoraceae from Panama including a new species of Camarophyllus and a new veiled species in Hygrocybe section Firmae. Fungal Diversity 32, 69-80.

Marian F, Brown L, Sandmann D, Maraun M, Scheu S. 2019 - Roots, mycorrhizal fungi and altitude as determinants of litter decomposition and soil animal communities in tropical montane rainforests. Plant and Soil 438, 1-18.

McGuire KL, Zak DR, Edwards IP, Blackwood CB, Upchurch R. 2010 - Slowed decomposition is biotically mediated in an ectomycorrhizal, tropical rain forest. Oecologia 164, 785-795.

McGuire KL, Allison SD, Fierer N, Treseder KK. 2013 - Ectomycorrhizal-dominated boreal and tropical forests have distinct fungal communities, but analogous spatial patterns across soil horizons. PLOS ONE 8, e68278

Moser M. 1983 - Key to Agarics and Boleti. Roger Phillips Publication.

Phillips R. 1981 - Mushrooms and Other Fungi of Great Britain and Europe. Pan Books Ltd, London.

Plassard C, Dell B. 2010 - Phosphorus nutrition of mycorrhizal trees. Tree Physiology 30, 11291139.

Read D, Perez-Moreno J. 2003 - Mycorrhizas and nutrient cycling in ecosystems - a journey towards relevance? New Phytologist 157, 475-492.

Singer R, Araujo I. 1979 - Litter decomposition and ectomycorrhizas in Amazonian forests. Acta Amazonica 9, 25-41.

Smith SE, Read DJ. 2008 - Mycorrhizal Symbiosis, 3rd Ed. Academic Press, London.

Vitousek PM. 1984 - Litterfall, nutrient cycling, and nutrient limitation in tropical forests. Ecology 65, 285-298.

Vitousek PM, Porder S, Houlton BZ, Chadwick OA. 2010 - Terrestrial phosphorus limitation: mechanisms, implications, and nitrogen-phosphorus interactions. Ecological Applications 20, $5-15$.

Watling R. 2001 - The relationships and possible distributional patterns of Boletes in South-East Asia. Mycological Research 105, 1440-1448. 
Watling R, Taylor A, See LS, Sims K, Alexander I. 1995 - A rain forest Pisolithus - its taxonomy and ecology. Nova Hedwigia 61, 417-429.

Xia S-W, Chen J, Schaefer D, Detto M. 2015 - Scale-dependent soil macronutrient heterogeneity reveals effects of litterfall in a tropical rainforest. Plant and Soil 391, 51-61.

Zhang L, Wang M-X, Li H, Yuan L et al. 2014 - Mobilization of inorganic phosphorus from soils by ectomycorrhizal fungi. Pedosphere 24, 683-689. 